\title{
Costs and the Plea Bargaining Process: Reducing the Price of Justice to the Nonindigent Defendant
}

In the United States, criminal defendants who cannot obtain free legal services face an unenviable choice. Like defendants who do qualify for state aid, they can elect to plead guilty or go to trial. But unlike the indigent, in making their decision they must consider the expense of trial, an expense they will have to bear even if acquitted. The present system of cost allocation thus creates a strong incentive for nonindigent defendants to plead guilty.

This incentive is particularly strong because of the prevalence of plea bargaining, which offers the nonindigent defendant both a reduction in the possible penal sanction and a substantial cost saving over trial in return for a plea of guilty. Although plea bargaining may appear to conflict with two primary goals of the criminal justice systemtruth determination and protection of the individual from the statethe Supreme Court has repeatedly upheld negotiated settlements. In the Court's view, as long as the bargaining process is itself fair, the individual defendant's informed expectations serve as an adequate safeguard against the most extreme kinds of prosecutorial pressure.

This Note applies the Court's analysis of prosecutorial pressure in the plea bargaining context to the issue of cost considerations for the nonindigent defendant. The Note demonstrates that cost considerations bring pressures to bear on nonindigent defendants that are qualitatively different from those presented by a prosecutor's sentencing and charge concessions; whereas the nonindigent defendant's informed expectations may serve as a safeguard against the latter, cost considerations pose a threat that is unremitting. The Note concludes that adoption of an indemnification provision for acquitted defendants is necessary to ensure that plea bargaining comports with the fundamental values the criminal justice system is designed to further.

\section{Criminal Costs in the United States}

The procedural protections mandated by the Constitution ${ }^{1}$ make the American criminal justice system among the most elaborate in the

I. These procedural protections include Fourth Amendment protection against illegal search and seizure and the accompanying exclusionary evidence rule, see Mapp v. Ohio, 367 U.S. 643 (196I); the Fifth Amendment ban on double jeopardy, see Benton v. Mary- 
world. These protections serve two overlapping and sometimes conflicting goals: truth determination and the protection of individual rights from encroachment by the state. ${ }^{2}$ But procedural protections are inherently costly, both for the state to provide ${ }^{3}$ and for the defendant to enjoy. ${ }^{4}$ In the United States, criminal costs, a necessary concomitant of procedural protections, usually lie where they fall.

\section{A. The Present System of Cost Allocation}

Although other countries have long awarded court costs and legal fees to criminal defendants acquitted at trial, ${ }^{5}$ the American criminal

land, 395 U.S. 784 (1969), and privilege against self-incrimination, see Malloy v. Hogan, 378 U.S. I (1964); Sixth Amendment rights to a speedy trial, see Klopfer v. North Carolina, 386 U.S. 213 (1967), trial by jury, see Duncan v. Louisiana, 391 U.S. 145 (1968), confrontation of accusers, see Pointer v. Texas, 380 U.S. 400 (1965), compulsory process for obtaining favorable witnesses, see Washington v. Texas, 388 U.S. 14 (1967), and assistance of counsel, see Argersinger v. Hamlin, 407 U.S. 25 (1972); and the Eighth Amendment protections against excessive bail or fines, see Stack v. Boyle, 242 U.S. 1 (1951), and cruel and unusual punishment, see Robinson v. California, 370 U.S. 660 (1962).

2. Truth determination-the separation of the innocent from the guilty-is a central concern of almost every criminal justice system. See Frankel, The Search for Truth: An Umpireal View, 123 U. PA. L. REV. 1031, 1033 (1975). But the American adversarial system also is based on a set of societal values that includes preservation of individual dignity and the protection of individual rights from encroachment by the state. See Williams $v$. Florida, 399 U.S. 78, 111-12 (1970) (Black, J., concurring in part and dissenting in part); Kadish, Methodology and Criteria in Due Process Adjudication-A Survey and Criticism, 66 YALE L.J. 319, 347 (1957). Thus the goal of the American criminal justice system is not only to protect the innocent from conviction, but also to preserve "the integrity of society itself" by "keeping sound and wholesome the procedures by which society visits its condemnation on an erring member." Fuller, The Adversary System, in VoICE OF AMERICA Forum Lectures 3 (1961).

Usually the procedural protections afforded the individual in the criminal process further both the goals of truth determination and protection of the individual. The Sixth Amendment right to counsel, for example, serves as a buffer between the individual and the power of the state but at the same time aids in the search for truth. See Tehan v. United States ex rel. Shott, 382 U.S. 406, 416 (1966) (“[T]o deny a lawyer's help through the technical intricacies of a criminal trial . . . is . . to infect a criminal proceeding with the clear danger of convicting the innocent."). Occasionally, however, the procedural protections guaranteed by the Constitution may impede the search for truth. M. FreEdMAN, LAWYERS' ETHICS IN AN ADVERSARY SySTEM 2 (1975) (requiring defendant to take stand may be effective means of truth determination yet defendant has absolute constitutional right to remain silent).

3. The total criminal justice expenditures by local, state, and federal agencies in 1972, including expenditures for police, correctional, judicial, prosecutorial, and defender services, was estimated to be $\$ 8.6$ billion. National Legal Aid and Defender Association, The Other Face of Justice 79, 81 (1973) [hereinafter cited as NLADA].

4. For a discussion of the staggering cost of properly defending a criminal prosecution, see Rosenn, Compensating the Innocent Accused, 37 OHIO Sr. L.J. 705, 711-12 (1976). Counsel fees for defending against a felony charge frequently run to several thousand dollars. In addition, a nonindigent defendant will have to pay for investigations, expert witnesses, court costs, and a bail bond premium that can itself cost $\$ 1,000$. Id. at 712 .

5. The method of repayment varies from country to country. In England, awarding costs is discretionary with the court. See G. Graham-Green, Criminal Costs 14-15 (1965); A. Kiralfy, The English Legal System $317-18$ (1967). In West Germany, the state pays 
justice system makes no such provision. ${ }^{6}$ In recent years there has been an expansion of the "loser pays" rule in many areas of civil litigation, ${ }^{7}$ but neither the federal government nor any state currently grants costs as a matter of statutory right to criminal defendants acquitted at trial. ${ }^{8}$

Moreover, the defendant has no effective judicial means for recovering the costs of winning acquittal. The prosecutor enjoys an absolute immunity from suits for malicious prosecution, ${ }^{9}$ and to maintain such an action against a third party, the acquitted defendant must meet a very difficult standard of proof. ${ }^{10}$ Civil actions for false imprisonment

the acquitted defendant's court costs and legal fees as a matter of course. See J. LANGBein, Comparative Criminal Procedure: Germanx 81 (1977). Yugoslavia and the Soviet Union have similar provisions. See Damaska, Evidentiary Barriers to Conviction and Two Models of Criminal Procedure: A Comparative Study, 121 U. PA. L. REv. 506, 553 n.104 (1973). Norway, Sweden, and Denmark provide legal services, including defense counsel, to all accused persons regardless of financial status. If the defendant is acquitted, no effort is made to collect for the services provided. See REPORT of THE ATTORNEY General's Committee on Poverty and the Administration of Federal Criminal Justice 32 (1963) [hereinafter cited as ATTORNEY GENERAL's REPORT]. In addition, the acquitted defendant in Norway may be compensated for any material loss he has suffered through prosecu. tion. See Bratholm, Compensation of Persons Wrongfully Accused or Convicted in Norway, 109 U. PA. L. REv. 839, 833 (1961).

One author has suggested that the presence of indemnification provisions for acquitted defendants in some countries and their absence in others may reflect the different emphases placed on an acquittal. If an acquittal can be interpreted as an affirmative finding of innocence, then the case for indemnification as a gesture of fairness to the acquitted is strong. But if acquittal has little relationship to the actual innocence of the defendant, the case for indemnification as an equitable gesture is weaker. See Damaska, supra, at 553 n.104. As this Note argues, however, in a country such as the United States where the vast majority of criminal cases are disposed of without trial, there are reasons other than post-trial equity for offering acquitted defendants the prospect of indemnification.

6. See A Note on American Law, 109 U. PA. L. REv. 845, 845-46 (1961).

7. See Note, Attorney Fees: Exceptions to the American Rule, 25 DRAkE L. REv. 717, 717 (1976). The "American Rule" requires that, absent a statutory provision to the contrary, each party to a lawsuit must bear his own legal costs. See Alyeska Pipeline Serv. Co. v. Wilderness Soc'y, 421 U.S. 240,247 (1975). However, at least 75 federal statutes currently authorize or require courts to award attorneys' fees as part of the relief granted in civil cases. See Berger, Court Awarded Attorneys' Fees: What is "Reasonable"? 126 U. PA. L. Rev. 281, 303 n.104 (1977).

8. See Rosenn, supra note 4 , at 705 (no such provision as of 1976). On at least one occasion, however, criminal defendants acquitted at trial have been awarded costs by the federal courts under existing statutory authority. See United States v. McLeod, 385 F.2d 734, 750 (5th Cir. 1967) (costs, including reasonable attorneys' fees, awarded under 42 U.S.C. $\$ 1971$ (c) (1976) when arrest made by sheriff to obstruct voter registration). For a discussion of the extraordinary relief granted in McLeod, see Lovell, The Case for Reimbursing Court Costs and $a$ Reasonable Attorney Fee to the Non-Indigent Defendant Upon Acquittal, 49 NEB. L. REv. 515, 515-16 (1970).

9. See Imbler v. Pachtman, 424 U.S. 409, 421-24 (1976) (noting prosecutor's common law immunity from malicious prosecution for actions taken in performance of duties).

10. The plaintiff in a malicious prosecution suit must show that criminal proceedings were initiated against him without probable cause and for purposes other than bringing an offender to justice. Sce RESTATEMENT (SECOND) of ToRTs $\$ 653$ (1977). Because the vast majority of criminal proceedings are initiated with probable cause, few acquitted de- 
against arresting officers who have acted without probable cause are usually unsuccessful, ${ }^{11}$ and to recover damages from the state or its agents under the most frequently applied federal statute, 42 U.S.C. $\S 1983,12$ an acquitted defendant must make the difficult showing that his civil rights have been violated. ${ }^{13}$ Finally, nonbusiness-related legal expenses are not deductible for federal income tax purposes ${ }^{14}$ and most defendants are not covered by prepaid legal insurance programs. ${ }^{15}$

\section{B. Mechanisms for Shifting and Reducing Criminal Costs}

The criminal justice system has not ignored the enormous cost burden that procedural protections can impose on both the individual defendant and the state. Two mechanisms have evolved to mitigate these costs: state provision of counsel, which shifts costs from the individual to the state, and plea bargaining, which reduces costs to both parties. But both of these mechanisms are of limited value to the nonindigent defendant.

\section{State Provision of Counsel}

The Supreme Court has held that the right to assistance of counsel is fundamental ${ }^{16}$ and has required the state to provide counsel to all defendants, faced with imprisonment, who cannot afford to provide their own. ${ }^{17}$ Many jurisdictions now provide a wide range of legal services to indigent defendants, including trial counsel, investigative

fendants can obtain relief via a separate civil action for malicious prosecution. See Lovell, supra note 8 , at 522-23. If the essential elements of the cause of action can be established, however, court costs and reasonable attorneys' fees can be recovered. See Restarement (SECOND) OF TORTS $\$ 671(\mathrm{~b}) \&$ (c) (1977).

11. See Rosenn, supra note 4, at 714 n.40. During a 12-year period in Los Angeles, $91 \%$ of all false imprisonment cases against police were unsuccessful, and damages in successful suits averaged only $.05 \%$ of the amount claimed. Coakley, Law and Police Practice: Restrictions in the Law of Arrest, 52 Nw. U. L. REv, 2, 5 (1957).

12. See 42 U.S.C. $\$ 1983$ (1976) (allowing any person injured by official misconduct that violates Constitution or federal law to sue party responsible in separate civil action). For a discussion of the history of $\$ 1983$, see Newman, Suing the Lawbreakers: Proposals to Strengthen the Section 1983 Damage Remedy for Law Enforcers' Misconduct, 87 YALE L.J. 447, 451-52 (1978).

13. See Project, Suing the Police in Federal Court, 88 YALE L.J. 781 (1979) (empirical study demonstrating difficulty of winning civil rights action against police).

14. See Comment, Equal Treatment for Criminal Defendants in the Allowance of a Tax Deduction for Legal Expenses, 67 J. Crm. L. \& CRminology 46, $46-47$ (1976) (proposing tax credit for all criminal defense expenses).

15. See Comment, supra note 14, at 64 . For a discussion of prepaid legal systems, see S. Krantz, C. Smith, P. Rossman, P. Froyd, \& J. Hoffman, Right to Counsel in Criminal CASES 294-98 (1976) [hereinafter cited as S. KRANTZ].

16. Gideon v. Wainwright, 372 U.S. 335,344 (1963).

17. The right to publicly provided counsel exists in all federal criminal cases. FED. $R$. Crim. P. 44(a). The right to public counsel applies to all state defendants accused of felonies and to all defendants accused of misdemeanors upon whom actual imprisonment 
services, expert witnesses, appellate counsel, and transcripts. ${ }^{18}$

Because these services are expensive, however, this cost shifting strategy is limited to defendants who cannot afford to pay. ${ }^{\mathbf{1 9}}$ The standards and procedures for determining eligibility for state-provided legal services vary considerably among jurisdictions. ${ }^{20}$ Despite the recent movement away from equating indigency with destitution, ${ }^{21}$ many jurisdictions still treat the determination of financial eligibility perfunctorily. ${ }^{22}$

The defendant who fails to qualify for public counsel, particularly a low- or middle-income defendant, is placed in a precarious position. As the Supreme Court has noted, such a defendant "who is just above the line separating the indigent from the nonindigent must borrow money, sell off his meager assets, or call upon his family or friends in order to hire a lawyer." 23 The limitation on publicly provided legal

is imposed. Argersinger v. Hamlin, 407 U.S. 25, 37 (1972). Absent waiver, no person may be imprisoned for any offense unless he was represented by counsel at trial. $I d$. Because Argersinger requires that a predetermination be made about the likelihood of both conviction and imprisonment, some commentators have proposed that counsel be appointed for all indigents who face the possibility of imprisonment. See, e.g., S. KranTz, supra note 15 , at 70 . Fifteen states presently employ such a standard. Id. at 71. But cf. Scott v. Illinois, 99 S. Ct. 1158, 1162 (1979) (Constitution does not require provision of counsel where imprisonment possible but not imposed).

18. The Federal Criminal Justice Act of 1964, 18 U.S.C. $\$ 3006 \mathrm{~A}$ (1976), authorizes the provision of services other than counsel for indigent defendants. See note 88 infra (discussing specific provisions). In most states, the granting of aid in addition to counsel is discretionary with the trial court. See Note, The Indigent's Right to an Adequate Defense: Expert and Investigational Assistance in Crininal Proceedings, 55 CoRNel. L. REv. 632, 635 (1970). At least 14 states make statutory provisions for such aid. Id. at 636 n.26 (listing states); see, e.g., MINN. Stat. ANN. $\$ 611.21$ (West Supp. 1979) (providing for “investigative, expert, or other services necessary to an adequate defense").

19. Providing free legal services to all defendants would require a significant expansion of federal and state budgets. One 1973 survey estimated the cost of providing "adequate" defense services to those defendants who already qualified as indigent would be $\$ 857$ million. See NLADA, sicpra note 3, at 79. Of the estimated $\$ 87$ million actually spent on indigent defense services in fiscal 1971-72, all but a small percentage was provided by state, municipal, and county governments. See S. KrANTz, supra note 15, at 303; cf. Scott v. Illinois, $99 \mathrm{~S}$. Ct. 1158, 1162 (1979) (any extension of right to counsel would "impose unpredictable, but necessarily substantial, costs" on states).

20. See S. KRANTZ, supra note 15 , at 309 .

21. See Hardy v. United States, 375 U.S. 277, 289 n.7 (1964) (Goldberg, J., concurring) (accused should be deemed indigent when lack of means prevents him from asserting rights at any stage of criminal process); AMERICAN BAR Association, STANDARDS RELATING to Providing Defense Services 53 (Approved Diaft 1968) (endorsing provision of counsel to any person financially unable to obtain adequate representation without substantial hardship). But see S. KRANTz, supra note 15, at 317 ("[u]nder most of the present systems, a substantial class of defendants-those who are not poverty-stricken but who will not or cannot retain competent private counsel for reasons of cost-are unrepresented").

22. See Y. Kamisar, W. Lafave, \& J. Israel, Modern Criminal Procedure 64 (4th ed. 1974) [hereinafter cited as KAMISAR \& LAFAVE].

23. Fuller v. Oregon, 417 U.S. 40,53 (1974). The nonindigent defendant may thus find himself at a serious disadvantage when compared to the indigent. See Argersinger v. Hamlin, 407 U.S. 25, 50 (1972) (Powell, J., concurring); D. OAks \& W. LehMan, A Criminal JUSTICE SYSTEM AND THE INDIGENT 150-51 (1968). 
services imposed by the state's finite resources thus can work substantial hardship on the nonindigent defendant. ${ }^{24}$

\section{Plea Bargaining}

The provision of counsel to indigent defendants does not reduce the total cost of the procedural protections required by the Constitution; instead, it shifts some costs from the defendant to the state. To reduce costs to both parties, a nontrial mode of case disposition-plea bargaining-has evolved to handle most cases. ${ }^{25}$

Approximately ninety percent of all federal and state convictions are achieved by means of the guilty plea. ${ }^{26}$ In the vast majority of these cases the pleas are negotiated. The prosecutor and defense attorney strike a bargain in which the defendant agrees to forego a jury trial and plead guilty in exchange for a concession from the prosecutor. ${ }^{27}$ Courts and commentators have identified several advantages, aside from the substantial cost saving to the defendant ${ }^{28}$ and the state, ${ }^{29}$ that plea

24. The Supreme Court has upheld state statutes that require convicted indigent defendants to reimburse the state for the cost of their defense when they become able to pay. See Fuller v. Oregon, 417 U.S. 40 (1974). But no state has attempted to require reimbursement from indigent defendants acquitted at trial. Such a requirement would further burden defendants upon whom the state had already imposed substantial hardship. Similarly, although many states "tax" court costs to convicted defendants, see Comment, Charging Costs of Prosecution to the Defendant, 59 GEo. L.J. 991,991 (1971), the Supreme Court struck down as unconstitutionally vague a Pennsylvania statute that allowed juries to tax costs to acquitted defendants. See Giacco v. Pennsylvania, 382 U.S. 399, 405 (1966). Thus, at least when it comes to a formal wealth transfer from the defendant to the state, the American criminal justice system does not look favorably upon the imposition of costs on acquitted defendants. See id. at 405 (Stewart J., concurring).

25. Ironically, the development of elaborate procedural safeguards to protect the individual from the state has led to the introduction of an alternative mode of disposition that circumvents many of those safeguards. See Langbein, Torture and Plea Bargaining, 46 U. CHr. L. Rev. 3, 8-11 (1978).

26. See D. Newman, Conviction: The Determination of Guilt or Innocence Withour Trial 3 (1966); Alschuler, Plea Bargaining and Its History, 79 Colum. L. Rev. 1, I (1979). In many jurisdictions the figure is much higher. See Langbein, supra note 25, at 9 n.11.

27. There is no obligation on the part of the court to accept the guilty plea. See J. Bond, Plea Bargaining \& Guilty Pleas $299-302$ (1978); cf. Weatherford v. Bursey, 429 U.S. 545 (1977) (plea bargaining not constitutional right). The prosecutor's concession usually takes the form of a recommendation for leniency in sentencing, an agreement to drop other pending charges, or an agreement to allow the defendant to plead guilty to a lesser included offense coupled with a dismissal of the more aggravated charge. See Note, Guilty Plea Bargaining: Compromises by Prosecutors to Secure Guilty Pleas, 112 U. PA. L. REv. 865, 866-68 (1964); cf. FED. R. CRIM. P. 11(e)(1) (authorizing such concessions).

28. The nonindigent defendant who pleads guilty can avoid the court costs and legal fees he would incur at trial. See note 4 supra. He also avoids the loss of time from work if he has made bail and an extended pretrial detention period if he has not. Such savings are particularly important if a suspended sentence is part of the plea bargain.

29. The full adversarial trial is expensive and time-consuming for the state. See Note, Plea Bargaining and the Transformation of the Criminal Process, 90 Harv. L. REv. 564, 566-67 (1977). Were all defendants to demand trials, the criminal justice system could not respond. See Santobello v. New York, 404 U.S. 257, 260 (1971). 
bargaining offers over trial. ${ }^{30}$ Nevertheless, plea bargaining remains a controversial mode of case disposition. ${ }^{31}$ Indeed, "[f]ew practices in the system of criminal justice create a greater sense of unease and suspicion than the negotiated plea of guilty." 32

Plea bargaining is troubling because it appears to threaten the underlying goals of truth determination and protection of the individual from the state. In theory plea bargaining is a limited strategy for reducing costs that induces only guilty defendants to forego their right to trial. ${ }^{33}$ But in practice the negotiated guilty plea offers advantages to innocent and guilty defendants alike. Commentators have identified several reasons why an innocent defendant who knows he did not commit the crime with which he is charged might decide to plead guilty. These include the overwhelming nature of the evidence against him, the size of prosecutorial concessions, the desire to protect third parties, the fear of additional prosecutions, pressure from family, the conditions of pretrial detention, and various self-destructive inclinations. ${ }^{3 \pm}$ If placed on trial, these innocent defendants might well be released. Plea bargaining thus threatens the goal of truth determination by increasing the chances that innocent defendants will be convicted. ${ }^{35}$

30. These additional advantages include enhanced self-determination, see Note, supra note 29, at 577; prompt punishment after the defendant's admission of guilt, a factor thought to make the defendant more amenable to the rehabilitative process, see Brady v. United States, 397 U.S. 742, 752 (1970); increased flexibility in sentencing, which allows the prosecutor to tailor the punishment to fit the needs of the individual defendant, see Newman \& NeMoyer, Issues of Propriety in Negotiated Justice, 47 DEN. L.J. 367, 376 (1970); and the avoidance of adverse publicity for both victim and defendant, see D. NewMan, supra note 26, at 96. But see Alschuler, The Defense Attorney's Role in Plea Bargaining, 84 YALE L.J. 1179, 1313-14 (1975) (discounting advantages of plea bargaining and arguing "cost of jury trials is worth paying").

31. See Note, supra note 29, at 564-65 (discussing extensive literature critical of plea bargaining).

32. President's Comm'n on Law Enforcement and the Administration of Justice, TASK FORCE REPORT: The Courts 9 (1967).

33. As used in this Note, the terms "innocent" and "guilty" refer to factual conditions rather than legal innocence and guilt. A factually innocent defendant is one who did not commit a voluntary criminal act with the requisite intent. In contrast, a legally innocent defendant is one who has charges against him dismissed for reasons of law or is acquitted by the trier of fact. See Barkai, Accuracy Inquiries For All Felony and Misdemeanor Pleas: Voluntary Pleas But Innocent Defendants? 126 U. PA. L. REv. 88, 98-99 (1977); cf. H. Packer, The Limits of the Criminal SAnction 166.68 (1968) (contrasting factual and legal guilt).

34. See Barkai, supra note 33, at 96-97; Note, Voluntary False Confessions: A Neglected Area in Criminal Administration, 28 IND. L.J. 374 (1953).

35. See Enker, Perspectives on Plea Bargaining, reprinted in KAMisar \& LAFAve, supra note 22, at 1096-98; Note, supra note 29, at 574-75; cf. note 85 infra (plea bargaining also convicts those factually guilty but legally innocent). The danger of innocent defendants pleading guilty is greatest in overcrowded urban court systems where harried public defenders, prosecutors willing to make substantial concessions, and the rigors of pretrial detention can combine to bring great pressure to bear on defendants to plead guilty. See 
In addition, the guilty plea represents a formal waiver of the constitutional protections embodied in the adversarial trial. ${ }^{30}$ Indeed, all nonjurisdictional claims to deprivation of constitutional rights are waived by the defendant who pleads guilty after consulting with reasonably competent counsel..$^{37}$ When consummated, the plea bargain substantially reduces the procedural protection offered the individual ${ }^{38}$ and convicts some defendants who, regardless of actual innocence or guilt, would have been acquitted at trial. ${ }^{39}$ Plea bargaining thus increases the chances that meritorious claims of deprivation of constitutional rights or valid procedural or substantive arguments will not be raised and thereby threatens all defendants.

The possibility of guilty pleas by either innocent defendants or defendants who would have been acquitted at trial is increased by the practices of prosecutors and defense attorneys. Prosecutors frequently offer the largest concessions to defendants against whom the state's case is weakest, ${ }^{40}$ and both public and private defense attorneys are subject to institutional and professional pressures to plead defendants guilty regardless of their chances for acquittal at trial..$^{41}$

Watergate Special Prosecution Force, Report 43 (1975). Although it is impossible to know how many innocent defendants plead guilty, one study has estimated that as many as one-third of the defendants who plead guilty in some federal courts would not have been convicted had they gone to trial. See Finkelstein, A Statistical Analysis of Guilty' Plea Practices in Federal Courts, 89 HARv. L. REv. 293, 309-10 (1975). Finkelstein suggests that a large number of these erroneously convicted defendants are factually as well as legally innocent. Id. at 310; see Alschuler, The Prosecutor's Role in Plea Bargaining, 36 U. CHI. L. REv. 50, 60-62 (1968) (discussing cases in which innocent defendants have pleaded guilty).

36. See Brady v. United States, 397 U.S. 742, 748 (1970). The rights waived include the privilege against self-incrimination, the right to trial by jury, and the right to confrontation. Boykin v. Alabama, 395 U.S. 238, 243 (1969).

37. See Tollett v. Henderson, 411 U.S. 258, 267 (1973). But cf. Blackledge v. Perry, 417 U.S. 21 (1974) (procedural challenge upheld despite defendant's plea of guilty).

38. In addition to removing the protection of a trial, plea bargaining reduces the impact of the exclusionary evidence rule so that illegally seized evidence can affect a defendant's decision to plead. See VerA INSTitute of Justice, Felony Arrests 125-26 (1977) [hereinafter cited as VERA]. Moreover, plea bargaining frequently acts to dissuade defendants from raising novel constitutional arguments. See Alschuler, supra note 35, at 81; cf. Tollett v. Henderson, 411 U.S. 258, 273 (1973) (Marshall, J., dissenting) (prosecutor may offer sentencing concession in exchange for defendant's agreement to drop challenge to grand jury selection process).

39. See W. Rhodes, Plea Bargaining: Who Wins? Who Loses? $44-47$ (Institute for Law and Social Research Publication 14, 1978) (empirical study concluding defendants who plead guilty in District of Columbia courts would have been acquitted at approximately same rate as those who contest charges at trial); Note, supra note 29, at 573 (plea bargaining allows prosecutors to convict defendants who would have been acquitted).

40. See Alschuler, supra note 35, at 58-60; White, A Proposal for Reform of the Plea Bargaining Process, 119 U. PA. L. REv. 439, 448 (1971). One survey that asked prosecutors to indicate their motivations for entering into plea bargaining found the strength of the state's case to be the most important motivating factor. See Note, supra note 27, at 901.

41. Public defenders and most private attorneys who handle criminal cases have a very heavy case load. High client-attorney ratios and an abbreviated lawyer-client relationship 
These threats to the goals of truth determination and protection of the individual inherent in negotiated justice have not gone unnoticed. The Supreme Court has held that to pass constitutional muster a guilty plea must be entered knowingly, voluntarily, and on the advice of counsel. ${ }^{42}$ Moreover, judges in many jurisdictions inquire into the factual accuracy of guilty pleas. ${ }^{43}$ But neither constitutional requirements nor the accuracy inquiry can prevent all false guilty pleas. The Supreme Court's test requires only that the guilty plea not be coerced and that the defendant understand fully the consequences of his action. ${ }^{44}$ When required, ${ }^{45}$ the accuracy inquiry typically consists of a cursory exchange between the judge and the defendant that lasts one or two minutes. ${ }^{40} \mathrm{~A}$ defendant who knows he is innocent or believes he will be acquitted at trial but still wishes to plead guilty will have little trouble doing so. ${ }^{47}$

are the norm. In this "assembly line" system of justice, the defendant is frequently assumed to be guilty and encouraged to plead. See Barkai, supra note 33, at 108-09. In addition, both public and private defenders may develop a greater allegiance to the bureaucratic system than to individual clients. By persuading his client to plead guilty, the defense attorney can maintain a good working relationship with the prosecutor with whom he must work again. See Alschuler, supra note 30, at 1180, 1222-24; Skolnick, Social Control in the Adversaty System, 11 J. Conflict Resolution 52, 60-68 (1967).

42. See, e.g., North Carolina v. Alford, 400 U.S. 25, 31 (1970).

43. See FED. R. CRIM. P. 11(f) (judge must inquire into accuracy of all federal guilty pleas). Though the precise form an accuracy inquiry must take remains obscure, see $\mathrm{J}$. Bond, supra note 27 , at 157 , the basic requirement in most jurisdictions is that the judge satisfy himself that a factual basis for the plea exists, see Barkai, supra note 33, at 95; American Bar Association, Standards Relating to Pleas of Guilty 30-34 (Approved Draft 1968). An argument can be made that false guilty pleas should be accepted once the defendant has been put on notice of any factual deficiency. See Alschuler, supra note 30, at 1296-97; Barkai, supra note 33, at 141 (because accuracy inquiry designed to protect defendant, he should be able to waive protection). This Note argues that it is more sensible to restructure the incentives offered innocent defendants so that false guilty pleas become less attractive than to attempt to thwart innocent defendants who believe it is in their best interest to plead.

44. See Brady v. United States, 397 U.S. 742, 754-57 (1970). Although a defendant may waive his right to counsel and still plead guilty, the courts will scrutinize such uncounseled pleas very carefully. See Von Moltke v. Gillies, 332 U.S. 708, 721-22 (1948); Note, supra note 29, at $564 \mathrm{n.4}$ (discussing reluctance to accept uncounseled guilty pleas).

45. Some states do nót require accuracy inquiries for felony pleas, see, e.g., Wilson v. State, 57 Wis. 2d 508, 513-14, 204 N.W.2d 508, 510-11 (1973) (no accuracy inquiry required for negotiated guilty plea in Wisconsin), and all but six do not require inquiries for pleas to misdemeanors, see Barkai, supra note 33 , at 93 n.30. The absence of a factual-basis requirement for pleas to misdemeanors takes on particular importance in view of the fact that a plea to a misdemeanor is frequently the end result of a felony charge reduced in the course of plea bargaining. See VERA, supra note 38 , at 6.8 (of 75,661 individuals arrested for felonies in New York City in 1971,30,803 had cases disposed of via guilty plea to misdemeanor).

46. See Barkai, supra note 33 , at 117 .

47. Innocent defendants who plead guilty can be divided into two groups: those who because of the complexity of the criminal law wrongly conclude they have committed the crime with which they are charged and those who know they did not commit the crime with which they are charged but conclude that it is nevertheless in their best in- 
Despite the fact that prosecutors, defense attorneys, and judges cannot be relied on to block false guilty pleas, ${ }^{48}$ the Supreme Court has repeatedly affirmed the constitutionality of plea bargaining. ${ }^{49}$ In the Court's view, it is the criminal defendant himself who will ensure that the goals of truth determination and protection of the individual are preserved in the plea bargaining process. The defendant, advised by competent counsel, has "full opportunity to assess the advantages and disadvantages of a trial as compared with those attending a plea of guilty," ${ }^{50}$ and is unlikely to condemn himself falsely. ${ }^{51}$ Because it is the individual defendant who is entrusted with the task of preserving the legitimacy of the plea bargain, an analysis of the impact of cost considerations on the plea bargaining process must focus on the effect of costs on the defendant.

\section{The Cost Incentive to Plead}

In response to constitutional challenges, the Supreme Court has held repeatedly that a defendant's informed expectations provide an adequate safeguard against formal prosecutorial pressures in the plea bargaining process. The Court's reasoning, however, is not applicable to costs, which bring qualitatively different kinds of pressures to bear on nonindigent defendants than do formal prosecutorial charging or sentencing concessions. Indeed, the combination of plea bargaining and present cost-allocation provisions places economic pressure on the nonindigent defendant that jeopardizes both the goals of truth determination and protection of the individual.

terests to plead guilty. See id. at 96-97. The accuracy inquiry is best suited to blocking guilty pleas from the former group. See McCarthy v. United States, 394 U.S. 459, 467 (1969) (accuracy inquiry intended to protect defendant who pleads knowingly and voluntarily but "without realizing that his conduct does not actually fall within the charge"). Presumably such defendants will cooperate with the judge at the accuracy inquiry and will, upon discovery of the factual deficiency in their guilty pleas, choose to go to trial.

The same is not true of the latter group. There is no reason to assume that such a defendant will cooperate at the accuracy inquiry. Indeed, if convinced the guilty plea is in his best interest, such a defendant is likely to do everything in his power to make the judge believe a factual basis for the plea exists.

48. See Finkelstein, supra note 35, at 310; cf. Alschuler, supra note 35, at 63 ("significant number" of prosecutors do not believe in guilt of defendants they prosecute).

49. See, e.g., Corbitt v. New Jersey, 439 U.S. 212, 226 (1978); Brady v. United States, 397 U.S. 742,758 (1970).

50. Brady v. United States, 397 U.S. 742, 754 (1970).

51. See Bordenkircher v. Hayes, 434 U.S. 357, 363 (1978). But see Alschuler, supra note 35 , at 64 n.43. 


\section{A. Truth Determination and the Plight of the Nonindigent Defendant}

The basic purpose of the jury trial guaranteed to criminal defendants by the Sixth Amendment is the determination of truth. ${ }^{52}$ But most criminal cases are resolved through plea bargaining rather than a jury trial. To preserve the integrity of the outcome of the criminal process in such cases, the Supreme Court has relied on the informed expectations of the defendant himself. This heavy reliance on the informed defendant as the guardian of truth in the plea bargaining process emerges clearly in Bordenkircher v. Hayes. ${ }^{53}$

In Bordenkircher the defendant was charged with writing a forged check for $\$ 88.30$, an offense punishable in Kentucky by one to ten years in prison. The prosecutor offered to recommend a five-year sentence in exchange for a guilty plea, noting that if the defendant did not plead guilty, he would seek a new indictment under a habitual offender statute that provided a mandatory life sentence upon conviction at trial. When the defendant refused the proffered concession, he was tried, convicted, and sentenced to life in prison..$^{54}$

In upholding the constitutionality of the prosecutor's conduct, the Court noted that guilty pleas legitimately can be induced by "promises of a recommendation of a lenient sentence or a reduction of charges, and thus by fear of the possibility of a greater penalty upon conviction after a trial." 55 From the standpoint of truth determination, the key assumption in this analysis is that the "fear of the possibility of a greater penalty upon conviction" will drive only guilty defendants to forego their constitutional rights. According to the Bordenkircher Court, "[d]efendants advised by competent counsel and protected by other procedural safeguards are presumptively capable of intelligent choice in response to prosecutorial persuasion, and unlikely to be driven to false self-condemnation."

To pretend charging or sentencing concessions as large as those offered the defendant in Bordenkircher have no effect on innocent defendants is unrealistic. ${ }^{57}$ But, because innocent defendants are likely to view their chances of acquittal at trial more favorably than will guilty defendants, ${ }^{5 s}$ the impact of such prosecutorial blandishments on

52. Tehan v. United States ex rel. Shott, 382 U.S. 406, 416 (1966).

53. 434 U.S. 357 (1978).

54. Id. at 358-59.

55. Id. at 363 .

56. Id.

57. See Langbein, supra note 26 , at 13 n.24; note 35 supra (some innocent defendants plead guilty).

58. See Landes, An Economic Analysis of the Courts, 14 J.L. \& EcoN. 61,69 (1971). 
guilty defendants is presumably much larger. Indeed, the assumption that formal prosecutorial concessions will have a differential impact is crucial to the Court's analysis in Bordenkircher.

Cost considerations, though usually not a formal element in plea negotiations, create an incentive ${ }^{59}$ for the nonindigent defendant to plead guilty quite apart from the concessions offered by the prosecutor. ${ }^{60}$ Unlike prosecutorial offers of leniency, however, the impact of the cost incentive to plead does not vary with the defendant's perception of his chances for acquittal at trial. Rather, it poses a fixed-cost barrier that acts to dissuade all defendants from going to trial. ${ }^{.1}$ When it comes to costs, there is no reason to assume, as the Supreme Court did with sentencing concessions in Bordenkircher, that the incentive to plead will affect innocent defendants any differently than guilty ones. ${ }^{62}$

59. The cost incentive to plead can be defined as the difference between the cost of going to trial and the cost of entering a guilty plea. In many jurisdictions, the nonindigent defendant will be able to plead guilty at little cost. See Alschuler, supra note 30, at 1183 (lawyers handling many clients will enter guilty plea for as little as $\$ 50$, although fees of several hundred dollars more common). In contrast, a one day trial can cost $\$ 1000$ or more in attorneys' fees alone. Id. at 1201; see Rosenn, supra note 4, at 712 (attorneys' fees for felony defense frequently several thousand dollars). Private defense lawyers are well aware of this differential. As Professor Alschuler reports:

Virtually all attorneys agreed that a guilty plea could be profitable when the defense attorney's compensation was a fraction of the amount necessary for a trial. Clients with limited resources may therefore find that they can pay an adequate fee for negotiating a guilty plea, but not enough to make a trial financially rewarding for a defense attorney.

In this in-between situation some lawyers ... inform a prospective client, "You know, this money is not enough to pay for a trial." If the client does not then indicate a willingness to plead guilty, these lawyers refuse to take his case. A client's limited financial resources may, in this way, provide a further source of pressure for a plea of guilty.

Alschuler, supra note 30, at 1201-02 (footnote omitted). An assistant United States attorney who specializes in the prosecution of white collar defendants reports that the cost of trial can be a "major factor" in the decision of nonindigent defendants to plead guilty. Interview with Robert Herbst, Deputy Chief, Special Prosecutions Division, U.S. Attorney's Office, E.D. Pa. (March 12, 1979) (notes on file with Yale Law Journal).

60. See Rosenn, supra note 4, at 716-17. Thus another reason should be added to the list of reasons, see p. 339 supra, why innocent defendants might falsely condemn themselves: to avoid the cost of trial.

61. The cost incentive to plead will have a relatively stronger effect on innocent, nonindigent defendants originally charged with misdemeanors than on those charged with felonies. Such defendants face a maximum sentence of one year should they go to trial, but can still incur sizable legal expenses in the process. The cost factor therefore is likely to bulk large in their calculations. See Landes, supra note 58, at $68 \mathrm{n} .16$ (smaller the possible sentence on conviction, greater the role costs will play in defendant's calculus). Moreover, because most states do not require accuracy inquiries for pleas to misdemeanors, see note 45 supra, those defendants given the relatively larger incentive to plead falsely will have an easier time doing so.

62. Conceivably, an innocent defendant may have an aversion to lying about his guilt. This "psychic loss" might induce some innocent defendants to go to trial even when a 
The cost incentive to plead, then, cannot meet the differential-impact requirement implicit in the Supreme Court's acceptance of formal prosecutorial pressure in the plea bargaining process. ${ }^{63}$ Cost considerations increase the chances that some innocent defendants will falsely condemn themselves. ${ }^{64}$ Because it affects innocent and guilty defendants alike, the cost incentive to plead is qualitatively different from the charge or sentencing incentives to which the Supreme Court has given its imprimatur, and poses a greater threat to the goal of truth determination. ${ }^{65}$

\section{B. The Cost Incentive to Plead and Protection of the Individual from the State}

In the United States, the criminal process is more than a means to the end of truth determination. It is also an end in itself." "Process" has value to society quite apart from the disposition of individual cases. ${ }^{67}$ Although at times it may resemble an obstacle course more than an efficient mechanism for determining truth, ${ }^{68}$ the criminal

guilty plea appears to be the preferable tack. See Landes, supra note 58 , at 69 . When weighed against the substantial pressures that can be brought to bear on innocent defendants, however, see note 35 supra, such a compunction to tell the truth can hardly be considered a sufficient safeguard against false guilty pleas.

63. Other considerations that cannot pass the differential-impact test also will enter into the defendant's calculus. The desire to protect friends, the fear of additional prosecutions, and the pressure from family (if it stems from fear of trial itself rather than fear of conviction), all bring pressures to bear on the defendant that are not mitigated by acquittal. These factors, however, are inherent in the criminal process and difficult to isolate and remedy. Costs, on the other hand, can be readily isolated and mitigated. See pp. 349-50 infra; note 5 supra (discussing foreign indemnification schemes).

64. Because acquitted defendants who did not make bail are not compensated for time spent in prison, pretrial detention can place particularly strong pressure on innocent defendants. See Foote, The Coming Constitutional Crisis in Bail: I, 113 U. PA. L. REv. 959, 961 (1965). In some cases, defendants who already have spent time in prison can plead guilty and face no further confinement. To such defendants, seeking acquittal offers no reduction in confinement but greatly increased costs. Thus pretrial detention, like costs, creates a strong incentive for a defendant to plead that does not vary with the defendant's perception of his chances for acquittal.

65. Because the Court has consistently upheld the practice of plea bargaining, see p. 342 supra, the boundaries of legitimate pressure remain ill-defined. The prosecutor may not act out of "vindictiveness." See Bordenkircher v. Hayes, 434 U.S. 357, 362 (1978). Nor may he make threats, misrepresentations, or improper promises to induce guilty pleas. See Brady v. United States, 397 U.S. 742, 755 (1970). Beyond this, however, the widest discretion is usually granted the prosecutor. See Bordenkircher v. Hayes, 434 U.S. 357, 372-73 (1978) (Powell, J., dissenting) ("Only in the most exceptional case should a court conclude that the scales of the bargaining are so unevenly balanced as to arouse suspicion.")

66. See Griffiths, Ideology in Criminal Procedure or A Third "Model" of the Criminal Process, 79 Yale L.J. 359, 398 (1970).

67. See generally Summers, Evaluating and Improving Legal Processes-A Plea for "Process Values," 60 CoRnell L. REv. 1, 3-4 (1974).

68. See H. PACKER, supra note 33 , at 163 . 
process, culminating in the adversarial trial, serves to air meritorious constitutional claims and to advance both substantive and procedural criminal law. In addition, it provides "a lesson in legal procedure, dignity, fairness and justice" not only for the individual defendant, but also for society ${ }^{69}$

Because law is advanced on a case-by-case basis, the vehicle for the vindication of this "process value" is necessarily the individual criminal defendant. The defendant who knows he has a valid claim, ${ }^{70}$ constitutional or otherwise, may choose not to air it. When he does, however, his stake in the outcome makes him a particularly effective guardian of society's interest. Thus the goal of protection of the individual embcdies a concern for the value of process not only to the individual defendant, but also to society.

The Fifth Amendment privilege against self-incrimination reflects this concern and is the "essential mainstay" of the adversarial system." Quite apart from its impact on truth determination, any kind of pressure placed on a defendant to incriminate himself is viewed with suspicion. ${ }^{72}$ Yet, the inducement of individual defendants to forego the expensive exercise of their constitutional rights and to incriminate themselves is the central purpose of the plea bargain. Plea bargaining necessarily results in a diminution of process values.

The Supreme Court has implicitly recognized this conflict between the protection of the individual and the inducement of pleas. ${ }^{73}$ In striking a balance between the two, the Court again has relied on the informed expectations of the defendant to further the goal of protection

69. See Griffiths, supra note 66 , at 398 .

70. Not all defendants will be aware of valid claims that can be raised at trial. See Barkai, supra note 33, at 96 (listing reasons why defendants with valid claims may erroneously conclude they are guilty). The presence of counsel is thus particularly important if the individual defendant is to serve as a vehicle for the vindication of process values in the criminal justice system. Cf. note 82 infra (counsel must be reasonably competent in order for guilty plea to be voluntary and intelligent).

71. See Malloy v. Hogan, 378 U.S. 1, 7 (1964).

72. See Miranda v. Arizona, 384 U.S. $436,442-44$ (1966). In the case of physical or psychological pressure during a custodial interrogation, the privilege against self-incrimination may also further the goal of truth determination. As a 19th century civil officer in India remarked, "it is far pleasanter to sit comfortably in the shade rubbing red pepper into a poor devil's eyes than to go about in the sun hunting up evidence." 1 J. Stephen, A History of the Criminal Law of England 442 n.l (1883). Even a defendant subjected to the more subtle pressures of modern criminal interrogation might well falsely confess to please interrogators. Nevertheless, "the basic purposes that lie behind the privilege against self-incrimination do not relate to protecting the innocent from conviction, but rather to preserving the integrity of a judicial system in which even the guilty are not to be convicted unless the prosecution 'shoulder the entire load'." Tehan v. United States ex rel. Shott, 382 U.S. 406, 415 (1966); see Griswold, The Right to be Let Alone, $55 \mathrm{Nw}$. U.L. REv. 216, 223 (1960) (privilege against self-incrimination "protects the guilty more often than it does the innocent").

73. See, e.g., Brady v. United States, 397 U.S. 742, 748 (1970). 
of the individual in cases in which "process" is most likely to be valuable. ${ }^{74}$ Underlying the Court's analysis of the legitimacy of formal prosecutorial pressures is the assumption that, regardless of his actual guilt or innocence, only the defendant who "sees slight possibility of acquittal"75 and has "nothing to gain"to from trial will succumb to prosecutorial pressures and plead guilty.

This assumption was carried to its logical extreme in North Carolina v. Alford.77 There the Court held it was not constitutional error for a state court to accept a guilty plea from a defendant, advised by counsel, who vigorously insisted he was innocent. ${ }^{78}$ The Court reasoned that whether or not he believed he was guilty, the defendant Alford, because of the strong evidence against him, "had absolutely nothing to gain by a trial and much to gain by pleading."'79 Thus, although plea bargaining may result in a diminution of procedural protection, only defendants who, like Alford, are advised by counsel that their chances for acquittal are slim and to whom procedural protection is worth relatively little will choose to forego that protection. ${ }^{80}$ Presumably, defendants advised by counsel that their chances of acquittal are good will continue to opt for trial, and the value of process to society will be preserved.

With regard to formal charge and sentencing concessions, this analysis is plausible. Although the system is not foolproof, a defendant, advised by counsel of the strength of the case against him, can discount any sentencing or charge concession by his perception of his chances for acquittal. ${ }^{81}$ Assuming counsel is reasonably competent, ${ }^{82}$ this per-

74. See, e.g., McMann v. Richardson, 397 U.S. 759, 768 (1970) (defendant who believes prior confession is crucial to state's case, but inadmissible, unlikely to plead guilty).

75. Brady v. United States, 397 U.S. 742,752 (1970).

76. North Carolina v. Alford, 400 U.S. 25, 37 (1970).

77. 400 U.S. 25 (1970).

78. Alford pleaded guilty to a second-degree murder charge, which carried a 30-year maximum sentence, to avoid the possibility of a death sentence upon conviction of firstdegree murder at trial. Although there existed strong circumstantial evidence of his guilt, Alford, in pleading guilty, insisted that he was innocent. Id. at 28-29.

79. Id. at 37 .

80. Cf. Finkelstein, supra note 35, at 294 (plea bargaining cases "manifest an assumption that those who are induced to plead guilty would, in any event, be convicted"). Whether or not a correspondence between the outcome of cases at trial and cases resolved through plea bargaining is a constitutional requirement, there are strong policy reasons for encouraging such a correspondence. See note 85 infra.

81. The value of a concession to a defendant is the product of two factors: the size of the concession and the defendant's perception of his chances for acquittal. Cf. Nagel \& Neef, The Impact of Plea Bargaining on the Judicial Process, 62 A.B.A. J. 1020, 1020 (1976) (defendant discounts possible sentence upon conviction by perception of chances for acquittal). When a defendant perceives his chances for acquittal as high, even substantial concessions can have a low value to him.

82. The Court has recognized the importance of competent counsel in the plea bargaining context, going so far as to permit defendants who have pleaded guilty to later 
ception will reflect not only the nature of the evidence but also claims of pretrial constitutional violations and procedural or substantive arguments. The defendant's informed expectations thus act as a powerful buffer between the individual and the state that encourages meritorious challenges and preserves process in those cases in which it will be most valuable.

With costs, however, no similar buffer of expectations exists. When the prosecutor initiates a criminal proceeding, the power of the state is brought to bear directly on the individual in the form of criminal costs. The nonindigent defendant must bear the cost of his encounter with the state regardless of the expected outcome at trial..$^{83}$ The cost incentive to plead thus affects the individual defendant's calculations in a particularly dangerous way. ${ }^{84}$ It circumvents the procedural protections built into the criminal process and makes it less likely that defendants with meritorious claims will choose to go forward. ${ }^{85} \mathrm{Be}-$

challenge their pleas on the ground that the advice they received was not within the range of competency demanded of attorneys in criminal cases. This is an exception to the rule barring defendants from raising post-plea claims of antecedent constitutional violations. See Tollett v. Henderson, 411 U.S. 258, 267 (1973); cf. McMann v. Richardson, 397 U.S. 759, 770 (1970) ("[w]aiving trial entails the inherent risk that the good-faith evaluations of a reasonably competent attorney will turn out to be mistaken").

83. This pressure will not be mitigated by the presence of counsel. Although the nonindigent defendant generally will have a lawyer before he pleads guilty, cf. note 44 supra (courts reluctant to accept uncounseled guilty plea), a lawyer can do very little to reduce the cost of trial. It might very well be in the defendant's best interests to plead guilty and avoid the cost and uncertainty of trial. See p. 339 supra (discussing reasons innocent defendants plead guilty). Arguably, it is counsel's duty to so advise him. See Alschuler, supra note 30 , at $1278-84,1296-97$ (discussing ethical dilemma of lawyer with client who asserts innocence but wishes to plead guilty, and arguing lawyer should abide by defendant's wishes).

84. In Bordenkircher, for instance, the Supreme Court, in accepting the constitutional legitimacy of formal prosecutorial sentencing and charging concessions, distinguished prosecutorial offers of adverse or lenient treatment to third parties, noting that such practices "might pose a greater danger of inducing a false guilty plea by skewing the assessment of the risks a defendant must consider." 434 U.S. at 364 n.8. It is precisely such a "skewing" that the cost barrier to trial produces. Both threats to third parties and the cost of trial produce incentives to plead that have no relation to the defendant's perception of his chances for acquittal or his actual innocence or guilt.

85. Some commentators argue that because many defendants who are acquitted at trial are in fact guilty, a short-circuiting of the criminal process, at least insofar as it convicts the guilty, is desirable. See Note, supra note 29, at 573-74; cf. Frankel, supra note 2, at 1032-41 (adversarial trial can impair search for truth). But this "short-circuiting" has its own costs. Frequently it is impossible for either the defendant or his lawyer to know before the trial whether the defendant's actions fit the elements of the crime. See Barkai, supra note 33 , at 141 n.329. For such a defendant the concepts of factual and legal guilt tend to merge and the objective truth exists only as it emerges from the fact-determining process at trial. See Enker, supra note 35, at 1098.

More important, however, even when the distinction between legal and factual guilt can be made, to argue that factually guilty but legally innocent defendants should be 
cause the buffer of expectations that softens the impact of formal prosecutorial concessions on all defendants is absent in the case of costs for nonindigent defendants, the cost incentive to plead poses a greater threat to the process values embodied in the goal of protection of the individual.

\section{Indemnification}

A criminal trial can put a substantial economic burden on all but the wealthiest of defendants. Whether a defendant is actually innocent or merely believes his chances of acquittal are high, the fixed-cost barrier to trial injects a factor into his calculations that undermines values important to the American criminal justice system. ${ }^{86}$ In order to reduce the cost incentive to plead guilty and to reconcile the treatment of costs with the Supreme Court's analysis of the formal incentives offered defendants in the plea bargaining process, an indemnification system that allows all acquitted defendants ${ }^{87}$ to recover court costs and those legal expenses reasonably necessary to his defense ${ }^{88}$ should

induced to plead ignores entirely the goal of protection of the individual, and the process value of trials. See p. 345 supra. Quite apart from its impact on truth determination, the cost incentive to plead is objectionable because it increases the chances of such shortcircuitings and jeopardizes these goals.

86. Cf. AtTorney General's Report, supra note 5, at 10 ("insofar as the financial status of the accused impedes vigorous and proper challenges, it constitutes a threat to the viability of the adversary system").

87. Alternatively, an affirmative finding of innocence such as the Scottish verdict of not guilty could be required for indemnification. See Lovell, supra note 8, at 531-33 (suggesting United States adopt tripartite choice given juries in Scotland of guilty, not guilty, not proven); Rosenn, supra note 4 , at 720 (only acquitted defendants who can prove innocence should be compensated). Or, indemnification could be at the discretion of the court, as it currently is in England. See note 5 supra.

This Note argues that granting costs should be automatic. In addition to the advantage of administrative simplicity, see Lovell, supra note 8 , at 528, such an automatic grant avoids stigmatizing those defendants who would be denied costs under a discretionary system. See Bratholm, supra note 5, at 843 . In view of the adverse impact an arrest or acquittal record can haye on the individual, the impact of denial of costs, in effect a finding that the individual is factually guilty but legally innocent, would be devastating. Although a system of automatic awards will unavoidably result in the indemnification of some guilty defendants, the denial of costs should not be used as a proxy for societal unease over the incidence of false acquittals. Cf. note 92 infra (if incidence of false acquittals too high, problem should be dealt with by readjusting procedural rules, not by denying costs).

88. The reasonableness of attorneys' fees can either be defined by statute, see Langbein, supra note 5 , at 82 (discussing German criminal fee schedule), or decided on a case-by-case basis, see Berger, supra note 7, at 282 (reasonableness criterion applied in civil cases by American judges). The Criminal Justice Act of 1964, 18 U.S.C. $\$ 3006$ A (1976), combines the two approaches in its provisions for payment of counsel appointed for indigent criminal defendants. It sets statutory ceilings on payments for counsel services, id. $\$ 3006 \mathrm{~A}(\mathrm{~d})(1)-(2)$ (\$30 per hour for counsel's court time, subject to $\$ 1000$ per 


\section{be adopted in the United States. ${ }^{89}$}

The cost to the state of indemnifying acquitted defendants will be much less than the cost of expanding state-provided legal services. ${ }^{90}$ Under such an indemnification system, the state and individual still can strike a mutually advantageous plea bargain in cases in which the defendant perceives his chances for acquittal to be low. Thus those defendants for whom plea bargaining was intended will continue to avail themselves of the system, and the cost savings to both parties will remain substantial. For other defendants, however, for whom trial holds a meaningful chance of acquittal-but only at a price-the guilty plea will no longer appear such an attractive alternative. The nonindigent defendant who must choose between pleading guilty and going to trial will no longer face a fixed-cost barrier regardless of the outcome of the trial. Rather, he will be able to discount the expected cost of going to trial by his perception of the probability of acquittal. ${ }^{91}$ The cost incentive to plead will decrease and the critical factor will become the defendant's perception of his chances of acquittal, not the cost of trial.

This shift in emphasis from cost of trial to probability of acquittal furthers the goals of truth determination and protection of the in-

attorney maximum for felonies), and services "other than counsel," id. $\$ 3006 \mathrm{~A}(\mathrm{e})(3)$ (\$300 per "person" who renders such services), but allows the trial judge or magistrate to waive such ceilings when necessary, $i d$. at $\$ \S 3006 \mathrm{~A}(\mathrm{c})(3),(\mathrm{d})(3)$. A similar provision could be adopted for indemnification of acquitted defendants.

89. Because many meritorious claims are vindicated on appeal, provision also should be made for reimbursement of reasonable trial and appellate costs to defendants who have their convictions overturned on appeal. In addition, because defendants are pressured to plead guilty at every stage of pretrial procedure and can incur sizable legal expenses before trial, provision should be made for indemnification of defendants who reach a given stage in the process and have all charges against them dropped. Because pretrial procedure varies considerably among jurisdictions, see L. KATZ, Justice is the Crime 247-365 (1972), the point at which the right to indemnification should attach will necessarily vary as well. In those jurisdictions where most dismissals occur before the filing of the indictment or information with the trial court, see, e.g., VERA, supra note 38, at 16 (less than $2 \%$ of felony arrests in New York disposed of by dismissal of charges after grand jury indictment), the formal filing of charges would be a possible point for indemnification to attach. As long as the defendant knows that if he prevails at any given pretrial stage he will be compensated for all reasonable expenses, including those incurred prior to that stage, he will have an incentive to press forward. The defendant against whom all charges are dropped before indemnification attaches will still have to pay his own legal expenses. The expenses incurred before charges are dropped, however, will necessarily be much less than those incurred in the course of a trial.

90. Acquittals account for as few as one percent of all criminal cases processed to a judicial conclusion. See Lovell, supra note 8 , at 528. And many of those acquitted already qualify as indigent. See NLADA, supra note 3 , at $71(65 \%$ of felony defendants and $47 \%$ of misdemeanor defendants indigent).

91. See note 81 supra. The defendant will not, however, be able to discount unreasonable expenditures for his defense, as such expenses cannot be reimbursed. The ceiling of reasonableness prevents extravagant expenditure induced solely by the prospect of indemnification. 
dividual. Although the possibility of guilty pleas by innocent defendants will not be eliminated, indemnification will permit nonindigent defendants to treat the cost incentive to plead in the same way that all defendants now treat formal sentencing and charge concessions. ${ }^{92}$ The economic pressure on innocent defendants to plead guilty will be reduced to a level the Supreme Court has found acceptable. In addition, the prospect of indemnification upon acquittal will serve as a needed buffer between the power of the state and the individual defendant. ${ }^{93}$ This buffer of expectations will encourage all defendants who perceive some value in an adversarial trial to exercise their constitutional rights. Indemnification, therefore, will increase process values not only to those defendants who prevail but also to society, which benefits from the airing of arguably meritorious claims at trial regardless of outcome.

\section{Conclusion}

Other countries have long compensated criminal defendants acquitted at trial out of a sense of elementary fairness to the individual

92. There is no assurance, of course, that there will be an exact correlation between the defendant's perception of his chances of acquittal at trial and his factual innocence or guilt. Although it seems reasonable to assume that factually innocent defendants perceive their chances of acquittal to be higher than do factually guilty defendants, see Landes, supra note 58, at 69 , there are many more factually guilty defendants in the criminal justice system. Some factually guilty defendants who perceive their chances of acquittal to be high might be induced by the proposed reform to go to trial and the number of false acquittals could increase.

This is not, however, a reason for rejecting indemnification. The problem of the false acquittal does not stem from the presence or absence of indemnification. Rather it is inherent in any criminal justice system. Because of its abhorrence of false convictions, the American system has chosen to tolerate a certain number of false acquittals. See In Re Winship, 397 U.S. 358, 372 (1970) (Harlan, J., concurring). If indeed the number of false acquittals that would obtain if all defendants went to trial is too high, the reasonable response is to adjust those procedural rules that contribute to false acquittals. See, e.g., Schlesinger, Comparative Criminal Procedure: A Plea for Utilizing Foreign Experience, 26 Buffalo L. REv. 36I, 385 (1977) (arguing for reevaluation of truth-defeating procedural rules). Given the inherent bias of the American system, the denial of costs, because of its identical impact on innocent and guilty defendants, is a particularly inappropriate "backdoor" through which to approach a reformation of the treatment of truth in the American criminal justice system.

93. There are, however, strong policy reasons for reimbursing defendants from funds not carmarked for the prosecutor's office. If costs were deducted from the prosecutor's budget, he would have an additional incentive to avoid acquittals. See Landes, supra note 58, at 63-65 (prosecutor maximizes convictions subject to budget constraint). Although such an incentive might serve to make him more circumspect in marginal cases involving innocent defendants, see Lovell, supra note 8 , at 527 , it also might lead to a reduction in the number of rightful accusations, see Bratholm, supra note 5, at 840-41. Moreover, a prosecutor faced with a reduction in his budget might very well respond by increasing the size of the sentencing and charge concessions offered to all defendants in the plea bargaining process. 
upon whom the state has imposed a substantial burden. In the United States, the inherent expense of constitutionally mandated procedural protections makes the cost of trial to the nonindigent defendant uniquely burdensome. ${ }^{94}$ Moreover, because the American defendant can conclude his case without trial, a practice unheard of in most European countries, the cost of trial affects the final outcome of the criminal process. Both from the standpoint of pretrial policy and posttrial equity, indemnification is particularly suited to integration into the American criminal justice system.

94. See Damaska, supra note 5, at 553 n.104. 